\title{
Inflation Targeting Framework and Interest Rates Transmission in Ghana: An Empirical Investigation
}

\section{Daniel Sakyi}

Corresponding Author: Department of Economics, Kwame Nkrumah University of Science and Technology (KNUST), Kumasi, Ghana, Email: dsakyi.cass@knust.edu.gh, Tel: +233 (0) 243708390

Isaac Osei Mensah

Bank of Ghana, 1 Thorpe Road, P.O. Box GP2674

\section{Samuel Kwabena Obeng}

Department of Economics, Kwame Nkrumah University of Science and Technology (KNUST), Kumasi, Ghana

\begin{abstract}
This paper investigates the long-and short-run rate of transmission of the prime rate to interest rates since the implementation of inflation targeting policy in Ghana. Monthly data covering the period January 2002 to March 2016 is used. The Johansen and Hansen parameter instability cointegration, the FMOLS and DOLS estimation procedures were used. The long-run results show incomplete pass-through of the prime rate to commercial banks' lending and deposit rates but over pass-through to the 91-day Treasury bill rate. The short-run adjustment shows relatively slow transmission of the prime rate to the respective interest rates. Given the findings, relevant policy suggestions are provided.

JEL Classification: C22; E43; E50

Keywords: inflation targeting, interest rates transmission, monetary policy, cointegration, Ghana.

Acknowledgement: Earlier versions of the paper were presented at the Centre for the Study of African Economies (CSAE) conference on 'Economic Development in Africa', at the University of Oxford, United Kingdom (20 ${ }^{\text {th }}-22^{\text {nd }}$ March, 2016) and the $13^{\text {th }}$ African Finance Journal Conference on 'Research Trends in Accounting, Finance and Economics for Africa's Development', in Accra, Ghana (18 ${ }^{\text {th }}-19^{\text {th }}$ May, 2016). Authors are grateful for comments made at these conferences and those made by the two anonymous reviewers of this journal as they have helped improve the current version. All errors that remain are the sole responsibility of authors.
\end{abstract}

Disclaimer: The views expressed in this paper are those of the authors and that they do not necessarily represent the views of the authors affiliated institutions. 


\title{
Inflation Targeting Framework and Interest Rates Transmission in Ghana: An Empirical Investigation
}

\begin{abstract}
This paper investigates the long-and short-run rate of transmission of the prime rate to interest rates since the implementation of inflation targeting policy in Ghana. Monthly data covering the period January 2002 to March 2016 is used. The Johansen and Hansen parameter instability cointegration, the FMOLS and DOLS estimation procedures were used. The long-run results show incomplete pass-through of the prime rate to commercial banks' lending and deposit rates but over pass-through to the 91-day Treasury bill rate. The short-run adjustment shows relatively slow transmission of the prime rate to the respective interest rates. Given the findings, relevant policy suggestions are provided.
\end{abstract}

JEL Classification: C22; E43; E50

Keywords: inflation targeting, interest rates transmission, monetary policy, cointegration, Ghana. 


\section{Introduction}

In the last two decades, central banks of advanced countries have introduced inflation targeting (IT) as an anchor for monetary policy, with relatively good results in most cases. Such countries include New Zealand, Czech Republic, the United Kingdom, Canada, and Sweden. As explained by Guy et al. (1998), many of these economies have focused on targeting the inflation rate instead of the traditionally used intermediate targets (money supply, interest rate and exchange rate). The former approach which focuses on the inflation rate itself is IT.

The argument put forward by IT central banks is that; (i) the former use of money supply as the main objective for monetary policy (based on the assumption that there is some stable relationship between changes in the money supply and inflation rate) is no longer reliable (Stals, 1999); (ii) practical experience has demonstrated that short-term manipulation of the money supply to achieve other goals (higher employment or perhaps enhance output among others) may conflict with price stability; and (iii) central banks often appear to get more public criticism for rising inflation rate than lower ones, although they are at the same time subject to constant pressure to reduce unemployment and/or increase output. The IT policy helps to address these concerns by making inflation rather than employment, output, or some other criteria the primary objective of monetary policy (Guy et al., 1998).

Under the IT policy, monetary authorities explain their decision to achieve price stability given that low and steady inflation rate contributes more to economic growth. The conduct of the IT policy is straight forward in theory. The central bank forecasts the future path of inflation; the forecast is compared with the target inflation rate ${ }^{1}$; the difference between the forecast and the

\footnotetext{
${ }^{1}$ The inflation rate the government believes is appropriate for the economy
} 
target determines how monetary policy has to be adjusted. IT central banks believe this policy has the ability to improve the performance of monetary policy in the medium to long term compared to the conventional procedures followed by non-inflation targeting central banks. What is crucial is that most of the IT policy countries have recorded significant falls in their levels of inflation although performances in developed countries dominate those in developing countries (see Mishkin and Schmidt-Hebbel, 2007; Kyereboah-Coleman, 2012).

Ghana formally adopted an IT framework as its monetary policy in May, 2007. Following this, the central bank announced price stability as its primary objective. However implicit (without formal announcement) IT actually started in January 2002. The Bank of Ghana (BoG) Act 2002 (Act 612) gave operational independence to the central bank, and established an implicit IT framework and Monetary Policy Committee (MPC) for the implementation of the new policy ${ }^{2}$. It is interesting to note that, the adoption of the IT policy saw domestic debt to GDP decrease from about 31\% in 2001 to $13.5 \%$ in 2006 and inflation also decreasing from about $41.9 \%$ in 2001 to around $12.7 \%$ in 2006 (Maureen, 2008). Ghana's five-year success with implicit IT policy encouraged the country to formally adopt the policy in 2007 which made it the second country (after South Africa) in subSaharan Africa.

Figure 1 shows the plot of the prime rate, the 91-day Treasury bill rate, the 182-day Treasury bill rate, the deposit rate, and the lending rate. As evident, all the series generally trend downwards during the period of IT policy. The trends of the financial market interest rates show high spread between the commercial banks deposit and lending rates as the deposit rates are relatively low compared to the lending rates. The high spread points to a likely disincentive to savings and high

\footnotetext{
${ }^{2}$ The goal and decisions of the MPC are communicated on regular basis to the general public.
} 
cost of borrowing to private investors. The Treasury bill rate however stayed higher compared to deposit rate of the commercial banks over the period, an indication of potential crowding out of private investment.

\section{FIGURE 1}

Despite the considerable fall in the prime rate ${ }^{3}$, commercial banks lend at high interest rates to private investors. This questions the effectiveness of the prime rate in influencing lending rates in the Ghanaian economy. The interest rate on deposit accounts falls almost directly with the prime rate but lending rates turns to be sticky downwards. Commercial banks have always attributed these anomalies to default risk associated with loans. For the IT policy to promote saving, investment and economic growth, it should be effective on movement in financial market interest rates and credit creation in the economy. This is crucial because, although the implementation of IT policy in Ghana has seen gradual fall of the previously high inflation rate (see KyereboahColeman, 2012), not all interest rates have responded adequately. Moreover, many empirical studies on this subject have focused on advanced countries with results rarely found in developing countries due to few countries adopting the policy.

Notwithstanding, it is important to note that although a number of studies on Ghana has been conducted on this same topic (see, for example, Abradu-Otoo et al., 2003; Acheampong, 2005; Ghartey, 2005; Amidu, 2006; CEPA, 2012; Kyereboah-Coleman, 2012; Fukac and Baldinin, 2014; Akosah, 2015), the present study make significant contribution. Aside the fact that we test the speed of adjustment of money market interest rates to the prime rate, similar to majority of the aforementioned studies, we go further to test asymmetric adjustment in the transmission of the prime rate to the respective interest rates. More so,

\footnotetext{
${ }^{3}$ The prime rate is the BoG monetary policy rate or indicator.
} 
the approach to examining asymmetry adjustment in the present paper differ substantially from those considered in the abovementioned papers on Ghana. This gives the present paper a different focus from other studies on Ghana. In addition, existing studies provided divergent results on the transmission of the prime rate to money market interest rates in Ghana.

The rest of the paper is structured as follows: The next section provides a brief overview of Ghana's financial system and banking structure. This is followed by a review of related literature in Section 3, and a discussion of the model, data and the estimation strategy in Section 4. The results are then reported and discussed in Section 5, after which the paper offers the implications of the results, and concluding remarks in the last Section.

\section{Ghana's financial system and banking structure: A brief overview}

The structure of Ghana's financial system has undergone transformation since the 1980s. The government initiated a financial liberalization policy under the Financial Sector Adjustment Program (FINSAP) in 1988, supported by the International Monetary Fund and the World Bank under the Economic Recovery Programme (ERP) in 1983. The main aim was to restructure the financial system and clean up nonperforming assets in order to make them viable and profitable (Aryeetey and Senbet, 2004). It was also meant to introduce technology, best practices in the business environment, and risk management system, aimed at creating healthy competition. Some of the reforms initiated under FINSAP, included fiscal and monetary operations, as well as privatization. The removal of the restrictions on foreign and domestic market entries, and the privatization of state-owned banks increased the number of commercial banks. Also, the liberalization in the banking industry led to the removal of interest rate controls and credit ceiling to allow banks compete for customers. The Exchange Control Act 1961 (Act 71) was replaced by 
the Foreign Exchange Act 2006 (Act 723) to eliminate the restrictions associated in the 1961 Act to a more liberalized foreign exchange regime (Quartey and Afful-Mensah, 2014).

Between 1990 and 2000 the number of banks in the country remained at 17, out of this 9 were commercial banks, 5 merchant banks, and 3 development banks. At the end of 2010, the number of Banks had risen to 26. Out of these banks, ownership was evenly distributed - 13 of them were Ghanaian owned banks and the remaining 13 foreign owned. As at September, 2016, there were 32 banks in Ghana with ownership structure as described earlier (BoG, 2016a). Rural and community banks which accounted for almost 5 percent of the banking system's total assets have also seen a significant improvement and by 2012 the number had risen to 133 reaching 137 in 2013 and 140 in 2016 (BoG, 2016b). There has also been a remarkable increase in registered non-bank financial institutions; from 57 in 2014 (PWC, 2014; Quartey and Afful-Mensah, 2014) to 66 in June, 2016 (BoG, 2016c).

It is important to note that the increase in the number of banks has reduced bank concentration as the market share of the dominant banks are gradually been distributed among new and emerging banks. For instance, Ghana Commercial Bank, Standard Chartered, Barclays Bank, and Social Security Bank together held 78.95\% share of total assets of the banking sector in 1990. However, their dominance has declined continually reaching 66.84\% in 1997, and 51.2\% in 2005 (OwusuAntwi and Antwi, 2013). However, the entrance of new banks did not make much impact on the dominance of the four commercial banks until the Ecobank Bank Ghana Ltd acquired The Trust Bank leading to a further decline in the market share of the top four banks to 38.6\% (Ziorklui, 2001 and PWC, 2014). Restructuring of the banking system in Ghana has indeed improved 
competition, therefore reducing dominance (Owusu-Antwi and Antwi, 2013). These developments are particularly important for the success of interest rate transmission in Ghana.

\section{Literature review}

\subsection{Theoretical background}

There exists a large and expanding literature on rules for the specification of the prime rate and how monetary policy-makers have reacted to deviations of actual inflation from their - explicit or implicit - target rates or levels. This notwithstanding, the best known of these rules is the Taylor rule for interest rate determination (Taylor, 1993), which represents the behaviour and preferences of the monetary authorities. It stipulates how much the central bank should change the prime rate in response to changes in inflation, output, or other macroeconomic conditions in the economy. In particular, the rule stipulates that for each one per cent increase in inflation, the central bank should raise the prime rate by more than one percent. This approach to monetary policy analysis by central banks begin in theory with the specification of the central bank's objective function and then derive the optimal rule for setting the prime rate in response to economic shocks. The prime rate deviates from the level consistent with the economy's equilibrium real rate and the target inflation if the output gap is nonzero or if inflation deviates from its target. A positive output gap leads to a rise in the prime rate as does a deviation of actual inflation above the target rate. The Taylor rule therefore gives a general rule for the determination of the prime rate by central banks with enough evidence from advanced countries.

\subsection{Empirical literature}

Some studies have focused on interest rates and its response to monetary policy decision in Ghana. In a related study, Ghartey (2005) finds a significant relationship between Treasury bill rate and the monetary policy rate (transmission mechanism from policy rate to Treasury bill rate) for Ghana 
for the period 1994-2004. Acheampong (2005) indicates variations in prime rate affects the lending interest rate but not the deposit interest rate. The paper examined the prime-rate-money-marketinterest rate channel in Ghana using time-series estimation methods and data spanning September 1994 to February 2014. It was concluded that money market rate (lending and deposit) respond sluggishly to the prime rate in Ghana. On the other hand, Akosah (2015) found the prime rate to be effective in signalling money market rates in long and short term rates but this effect was considered incomplete (i.e., not one-to-one). In a cross sectional study of 18 universal banks, it was found that the effect of the prime rate on the lending rate of banks in Ghana though negative was insignificant (Amidu, 2006). This indicates that universal banks did not respond to monetary policy decisions as expected. Kovanen (2011) analysed interest rate pass-through using time series and panel bank-specific data of 20 largest banks in Ghana during the period 2005 to 2010. The focused variables were the interbank market interest rate and the 91-day Treasury bill interest rate which are expected to be relevant bench mark for pricing of retail lending and deposit rates. The findings suggest, the interbank interest rate respond to changes in the BoG's prime rate with one month lag in all the models estimated. Long run deviation in the interbank interest rate from the prime rate nonetheless suggests the prime rate may not always have provided an accurate reference point for the interbank rate due to uncertainty. CEPA (2012) further shows that the prime rate largely influences the short term interest rates (91-day Treasury bill rate and the interbank rate) relative to long term rates. Notwithstanding, these studies there is clear evidence of significant reduction of inflation rate and volatility with fairly rapid adjustment to long run equilibrium in the IT policy regime (Kyereboah-Coleman, 2012; Bawumia and Abradu-Otoo, 2003). However, the effectiveness of the IT policy on interest rates transmission remain crucial for monetary policy to address in Ghana. 
Regarding the empirical literature elsewhere, there have also been diverse views concerning monetary policy transmission under IT regime reported by several studies. Examples of such studies include Charoenseang and Manakit (2007) who investigated monetary policy transmission in an inflation targeting era in Thailand from June 2000 to July 2006. By employing Engle-Granger co-integration and the error-correction model, they analysed the relationship between the prime rate and the financial market interest rates. There was only a small pass-through effect of the prime rate to financial market interest rates. On the average, the commercial banks' lending rates tend to adjust lower than the deposit rates consistent with the findings by Chong et al. (2006) who stressed that lending and deposit rates, are more rigid and take much time in responding to monetary policy surprises, a situation which has been attributed to information asymmetry in the banking system. With asymmetric adjustment analysis, the commercial bank's lending rates took more time to adjust to the prime rate compared with those of deposit rates.

Froyen and Berument (2009) studied interest rates transmission under IT regime in New Zealand by Vector Autoregressive (VAR) estimates using monthly data. They looked directly at the impact of innovations in the prime rate on long-term interest rates in a pre and post IT regime. During the period of IT (i.e. 1992-2008) both short-term and long-term interest rates in New Zealand were lower and less volatile than in the pre-IT period. The response declined even more when only the post-1994 period was considered. Thus, greater anchoring of inflationary expectations is a possible reason for this decline. However, Roley and Sellon (1995) suggested that many empirical studies found only a weak relationship of the impact of policy actions on interest rates.

Hemachandra (2011) examined the relationship between the prime rate and other macroeconomic variables in Sri Lanka using the OLS estimation method. The study found out that 1 percent 
increase in the prime rate increased the Treasury bill rate by 1.20 percent. The current and previous prime rates were also found to influence current deposit rate of the commercial banks. Specifically, a 1 percentage increase in previous prime rate increased the current weighted average deposit rate by 0.69 percent significantly. Thus not only current prime rate but historical prime rates will have effect on deposit rates. Misati et al. (2011) studied the size and speed of interest rate in Kenya and found incomplete pass-through in both the short-and long-run.

\subsection{Asymmetric adjustment process: A survey}

Asymmetric adjustment process appears to be rather common and has been reported by Kleinmeier and Sander (2006) for the Southern African Customs Union (SACU) region and Kwapil and Scharler (2010) for the U.S. and the Euro zone. A wide range of literature on the asymmetric adjustment of interest rate cover advanced economies. Most of these studies found the interest transmission process to be sluggish and asymmetric in advanced economies with little evidence for developing countries (Malile, 2013).

Several indicators in the financial system contribute to the asymmetry of interest rate pass-through. Roelands (2012) and Jamilov and Egert (2013) attributed it to factors such as the level of liquidity in the banking sector, capital and liquidity requirements of banks, maturity mismatch of the assessment of credit risk by banks, maturity mismatch of loan and deposit portfolio, level of economic growth, level of competition in the banking sector, type of bank customers, credibility of monetary policy, among others.

The study by Roelands (2012) confirms that capital constraints make banks charge higher lending interest rate with slow pass-through of the Federal Fund rate using interest rate data in the US economy. Jamilov and Egert (2013) investigated the asymmetric adjustment of interest rate for 
Armenia, Azerbaijan, Georgia, Kazakhastan, and Russia using monthly interest rate data in an ARDL model. The study found some asymmetric effect for only Georgia and Kazakhastan though not statistically significant. In another study, Sznajderska (2012) investigated asymmetric adjustment of deposits and lending rates in Polish commercial banks to changes in interbank rates during the period 2004-2011. The findings suggest that banks are faster in adjusting their rates for credits when the error correction term is below their threshold values in Poland.

Other studies have identified menu costs (Hofmann and Mizen, 2004) and collusive hypotheses (Hannan and Berger, 1991) to be the primary factors of the rigidities in interest rates adjustment. Interest rate pass-through may be incomplete due to the cost associated with continuous adjustment. Such costs may be menu costs, information costs, and non-pecuniary costs associated with adjustments (Hofmann and Mizen, 2004). Menu cost involves the cost of changing pricelist and expenditure on adverts to notify customers about products, a situation which is costly and time consuming for banks and financial institutions (Madsen and Yang, 1998). In the face of these costs, pass-through can only be complete when changes in prime rates are significant and permanent (Cottarelli and Kourelis, 1994; Dutta et al., 1999). In addition, anticipated changes must be successive and in the same direction. Hence, the market will hardly respond to minor changes in prime rates. The reason is that, menu costs create flat profit functions with limited incentive to vary rates when the changes in prime rates are small (Hofmann and Mizen, 2004).

Lowe and Rohling (1992) provide a further explanation to interest rate rigidities as switching cost. The study found that mortgage interest rates in Australia were sticky downwards due to switching cost. They explained switching costs such as loan establishment fees, stamp duty, early repayment fees associated with moving from one housing loan to another. This is likely to deter borrowers from switching to another financial institution to access loan. 
Hannan and Berger (1991) discusses the collusive behaviour of banks in the financial market. They explained that if the banking sector is either concentrated or less competitive, it is more likely for banks to use their market power to maximize profits. Such collusion is however likely to break down with changes in prices. Break down in collusion is associated with greater costs when deposit rates increase compared to when they decrease. However, the opposite cost effect holds for lending rates. Moreover, lags between changes in interest rates and the reactions of customers to such changes bid up costs associated with deposit rates. Hannan and Berger (1991) therefore explains lending rates as being rigid downwards whereas deposit rates are rigid upwards.

Scholnick (1996) provides evidence of asymmetric response between lending and deposit rates in the banking industry in Malaysia and Singapore caused by collusive behaviour. Lim (2001) reports that collusive bahaviour among banks leads to sticky lending and deposit rates in the short-run. Deposit rates have been found to be rigid upwards in many studies in asymmetric adjustment models given that banks in concentrated markets are less likely to change deposit rates (Carlton, 1986; Hannan and Berger, 1991). The size, number of banks, the degree of competition and structure of the banking system influence the stickiness of financial market interest rates (Cottarelli and Kourelis, 1994, Biekpe, 2011). Other factors such as constraints associated with the movement of capital and entry barriers account for the sluggish adjustments in rates (see Cottareli and Kourelis, 1994).

\section{Empirical methodology}

\subsection{Empirical model}


To examine the long-run relationship and ascertain the degree of transmission of the prime rate to market interest rates in Ghana, the paper follows the modelling technique of Cook and Hahn (1988) and Charoenseang and Manakit (2007) and specifies the following equation.

$I_{t}=a_{0}+a_{1} P R_{t}+\varepsilon_{t}$

where $I_{t}$ represents the interest rates (i.e. lending rate, deposit rate or Treasury bill rate) endogenously determined in the financial market, $P R_{t}$ represents the prime rate, $\varepsilon_{t}$ is the stochastic error term with zero mean and constant variance. $a_{0}$ measures the constant mark up. The long-run parameter $a_{1}$ indicates the rate of transmission of the prime rate to the respective interest rates. The rate of transmission is expected to be between zero and one. The long-run adjustment is complete when $a_{1}$ is equal to one and is incomplete when it is less than one. However, over pass-through will make the value to be greater than one. A complete pass-through means that changes in the prime rate is transmitted in equal proportion to the respective interest rate. Theoretically, this paper expects the prime rate to be positively related to the interest rates. Inflation does not enter the model if economic agents' expectation of inflation coincides with that of the monetary authorities captured by changes in the prime rate. Ceteris paribus, economic agents pay little attention to inflation when they believe monetary authorities will commit to the set inflation target and price stability.

The short-run adjustment of the interest rates to changes in the prime rate is examined through the error-correction procedure if the variables in equation (1) are co-integrated. In this case, the paper estimates the Error-Correction Model (ECM) of the following form;

$\Delta I_{t}=\beta_{0}+\sum_{j=1}^{P} \beta_{1 j} \Delta P R_{t-j}+\sum_{j=1}^{P} \beta_{2 j} \Delta I_{t-j}+\beta_{3} E C T_{t-1}+\mu_{t}$ 
where $\beta_{0}$ and $\beta_{1}$ are short-run intercept and prime rate coefficients respectively. The prime rate coefficient $\beta_{1}$ is interpreted as a short-run transmission parameter. $\Delta$ is the first difference operator, $\mu_{t}$ denotes the error term, $E C T_{t-1}$ is the lagged error correction term computed from the long-run cointegrated relationship of equation (1) with the formula $E C T_{t-1}=I_{t-1}-\alpha_{o}-\alpha_{1} P R_{t-1} \cdot \beta_{3}$ which represents the error correction adjustment speed when the interest rates are away from their equilibrium levels is expected to be negative and statistically significant. Under the assumption of cointegration the mean adjustment lag (MAL) of a complete transmission is calculated by $\left(1-\beta_{1}\right) / \beta_{3}$.

The adjustment speed of the interest rates may differ when they are below or above the long-run equilibrium (Chong et al., 2006). This result is crucial as the financial market is often slow in responding to monetary policy surprises due to the presence of information asymmetry (moral hazard and adverse selection) which makes commercial banks charge high interest rate rather than reducing loans supply as explained by De Bondt (2005). Within this context, commercial banks will only reduce their base rate if they expect continuous decline in the prime rate. On the other hand, the fear that borrowers will default leads to higher constant mark-up raising the lending rates. Further explanation to information asymmetry is that commercial bank interest rates are administratively determined which respond slowly to small changes in the prime rate (Dutta et al., 1999). The banks will respond only when they expect the monetary policy authorities to commit to either reducing or increasing its rate significantly. Also, investors in financial markets are often less likely to switch to different financial products due to limited information on interest rates, particularly under imperfect competition (Hannan and Berger, 1991). Lastly, due to high switching costs, economic agents may not shift to other products/institutions (Heffernan, 1997) when prices 
change leading to price rigidity in the financial market. All these factors may explain the stickiness in the interest rates in adjusting fully to changes in the prime rate.

In testing for information asymmetry in the financial market interest rates when they are above or below their equilibrium levels, the dummy variable $(d)$ is used in the asymmetric adjustment as specified by Chong et al. (2006) and shown in equation (3).

$\Delta I_{t}=\pi_{0}+\pi_{1} \Delta P R_{t}+\pi_{2} d E C T_{t-1}+\pi_{3}(1-d) E C T_{t-1}+e_{t}$

where $d=1$ if the residual $E C T_{t-1}$ is positive and 0 if it is negative. To test the difference in adjustment speed, the standard Wald test is employed. The difference in the adjustment speed is attributed to information asymmetry in the financial market. Faster adjustment is anticipated when the expected difference between the current prime rate and the future prime rate is large, while a slower adjustment is expected if the reverse holds true.

\subsection{Data}

Monthly data covering the period January 2002 to March 2016 is used. The data for the prime rate (PR) and the interest rates - the 91-day Treasury bill rate (TBILL91), 182-day Treasury bill (TBILL182), commercial banks' lending rate (LR), and commercial banks deposit rate (DR) are obtained from the database of the BoG. The Treasury bill rates are the interest rates offered in the open market in order to attract funds from the general public. It is the major source of government borrowing to finance maturing debt and budget deficits. Lending rates are charged by commercial banks on loans advanced to the private investors and consumers. In this paper the lending rate is proxied by the commercial banks' lending rate which forms the basis for determining all other sectors interest rates. Deposit rate is the interest rate paid to savers by commercial banks. 
Commercial banks pay different rates on deposits depending on how long savers are willing to keep their funds under different conditions. The current paper makes use of the 3-month deposit interest rate as proxy for deposit interest rate.

\subsection{Estimation strategy}

In order to avoid the generation of spurious results normally associated with time series data, the variables require testing for the existence of unit root. This paper makes use of the parametric Augmented Dickey-Fuller (ADF) unit root test by Dickey and Fuller (1979; 1981), the nonparametric Phillips-Perron (PP) unit root test by Phillips and Perron (1988) and the Zivot-Andrews (Zandrews) test by Zivot and Andrews (1992) which controls for one structural break. The relevance of the unit root testing is to determine the order of integration of the variables. In each test, the null hypothesis of unit root (non-stationarity) is tested against the alternative hypothesis of the absence of unit root (stationarity). Tables A.1.1 - A.1.3 (see the Appendix) report the results of the unit root tests according to ADF, PP and Zandrews unit root tests respectively. According to the ADF and PP results, all the variables considered are integrated of order one or $I(1)$ at $1 \%$ level of significance. These outcomes are further confirmed by the Zandrews test as the null hypothesis of unit root without a structural break is not rejected at the $5 \%$ level of significance for all variables. That is, regardless of the unit root testing procedure used, all the variables can be treated as integrated of order one or $I(1)$.

The prime rate is assumed to move closely with the financial market interest rates. Therefore, the paper examined the presence of cointegration relationships among the variables using the Trace test within the framework of the Johansen (1991) cointegration test procedures and the Johansen et al. (2000) cointegration procedures which controls for structural break(s) in the series. The 
Johansen cointegration Trace test results without and with structural break(s) are reported in columns 1 and 2 of Tables A.2.1 - A.2.4 respectively (see the Appendix). The results clearly show there is evidence of cointegration in all the estimated models (except that for TBILL182) at least at the $5 \%$ level of significance levels. Since no cointegration relationship is found between TBILL182 and the prime rate, in what follows we do not consider results related to this relationship. In the case of the other variables (LR, DR and TB92), the evidence of cointegration validate the use of the ECM in equation (2) for the analysis as a further examination of the coefficient of the error-correction term ( $\left.\beta_{3}\right)$ (see Table 2). As evident these coefficients are all negative and highly significant indicating valid long-run relationship among the variables.

\section{Empirical results and discussion}

This section of the paper reports and discusses the estimated long-run transmission of the prime rate, short-run dynamic adjustment process and the asymmetric short-run adjustment results. The long-run results presented in Table $1^{4}$ were obtained by estimating equation (1) using the Fully Modified Ordinary Least Square (FMOLS) and the Dynamic Ordinary Least Square (DOLS). As often argued, these estimates are more robust in the presence of serial correlation and heteroscedasticity usually associated with time series data (Phillip, 1995).

All the interest rates are positively related to the prime rate and highly significant according to the FMOLS and DOLS estimates. The long run estimates show the responsiveness of the market interest rates to the monetary surprises (indicated by changes in the prime rate) of the central bank. The short term money market interest rate depicts an over pass-through as indicated by the

\footnotetext{
${ }^{4}$ In this Table we also report the Hansen parameter instability cointegration test (Hansen 1992) associated with the FMOLS and DOLS. Hansen test has the null hypothesis that the series are cointegrated. As evident the $p$-values which are $>0.2$ are all not significant. This provides additional support for the cointegration results reported earlier.
} 
coefficients of the TBILL91 (1.1541 and 1.2002 for FMOLS and DOLS estimates respectively). Thus, the 91-day Treasury bill rate responds more than proportionately to changes in the prime rate. The high responsiveness of the Treasury bill rate proves its competiveness as against the other market interest rates which further reflect the effectiveness of the central bank in the management of credit to control inflation in the open market. Moreover, regular interventions by the monetary authorities to raise Treasury bill rate to finance maturing debt can also result in the over-passthrough. Although, there is incomplete pass-through in both the lending (0.6531 and 0.6579 for FMOLS and DOLS estimates respectively) and deposit rates (0.3201 and 0.3197 for FMOLS and DOLS estimates respectively) of the commercial banks, the lending rate is more responsive to the prime rate. The lending rate happens to be more competitive in the long-run relative to the deposit rate. This finding suggests a form of collusive behaviour among the banks as deposit rate appear to be more rigid upward than lending rate (see, for instance, Hannan and Berger, 1991). The result is not consistent with the findings of Amidu (2006) who found a negative but insignificant relationship between the prime rate and the lending rate. It is worth noting that, as expected, FMOLS and DOLS results are similar even though the magnitude of the coefficients differ.

\section{INSERT TABLE 1 HERE}

The short-run estimates (see Table 2) show that the short term money market interest rate (91-day Treasury bill rate) is highly significant at $1 \%$ level. This confirms that the money market rate is highly responsive to changes in the prime rate both in the short-and long-run, possibly making the short term rate an effective instrument to managing domestic credit (demand) and hence inflation. As shown in Table 2, it takes about 2-3 months (i.e. about 2.875) for the 91-day Treasury bill (TBILL91) to respond completely to the prime rate, making them relatively more competitive in 
the financial market as shown by their Mean Adjustment Lag (MAL). The result is consistent with the findings of Acheampong (2005) for Ghana and Mahasi and Pokhriyal (2013) for Kenya. The lending and deposit rates of commercial banks are the most sluggish in adjusting to long-run equilibrium taking approximately 13 months (12.99 and 13.115) respectively as shown by their MAL. It can be explained that only when the commercial banks expect permanent and significant changes in the prime rate will they have the incentive to adjust the lending and deposit interest rates according to the menu cost hypothesis (Cotarrellia and Kourelis, 1994). Commercial banks have also explained that high default risks and non-performing loans contribute to the unwillingness to reduce lending rates significantly when the prime rate falls consistently (De Bondt, 2005). In the short run, all the variables show incomplete pass-through. The short-run results for the 91-day Treasury bill rate shows it is more competitive than the others since its coefficient is the highest $(0.7700)$.

\section{INSERT TABLE 2 HERE}

The standard Wald test is used to test the speed of adjustment when the rate of transmission is above or below equilibrium in the presence of information asymmetry. The null hypothesis $\pi_{2}=\pi_{3}$ states no difference in the adjustment speed, while the alternative hypothesis of $\pi_{2} \neq \pi_{3}$ means otherwise when the prime rate transmission is either above or below equilibrium (Chong et al., 2006). The results (see Table 3) shows the 91-day Treasury bill (TBILL91) rate adjust faster from above equilibrium (4.5 months) than when it is below equilibrium (5.4 months). The fact that the TBILL91 adjusts faster to equilibrium depicts high degree of its responsiveness to the prime rate in the financial market. From Table 3, the adjustment speed differs in the DR as its probability value is greater than $5 \%$ by the Wald test implying little significance of information asymmetry in 
the adjustment process. Stated differently, the Wald test is not significant in the DR showing that information asymmetry plays little role in its adjustment process. The adjustment speed is also longer here (27.6 months from above equilibrium and 45.9 months from below equilibrium). However, the test shows the significance of information asymmetry in the commercial bank lending rates. The LR responds faster when it is above equilibrium (i.e. 20.3 months) than when it is below equilibrium (i.e. 31.5 months) even though both rates of adjustment are sluggish. Kovanen (2011) explained these variations as follows; during periods when the prime rate has been falling, the convergence of market interest rate towards the long-term equilibrium appears to be faster and statistically significant. On the other hand, during periods of rising prime rates, the convergence is not statistically significant.

\section{INSERT TABLE 3 HERE}

\section{Concluding remarks and policy recommendations}

This paper has investigated the rate of transmission of the prime rate to financial market interest rates in Ghana for the period January 2002 to March 2016. The Johansen and Hansen parameter instability cointegration, the FMOLS and the DOLS estimation procedures were used. The long run results reveal that the prime rate is crucial in determining interest rates in Ghana. The prime rate was found to be significant in determining the lending, deposit and the 91-day Treasury bill rate in the financial market especially in the long-run. The rate of transmission, however, differs depending on the type of interest rate under consideration. The 91-day Treasury bill rate shows over-pass-through making it the most responsive in the market, signalling its effectiveness in managing liquidity and stabilizing the economy. There is incomplete pass-through in the commercial banks' deposit rate whiles the lending rate is almost complete. In the short-run, the 
effect of the prime rate on the deposit rate was not significant while that on the lending rate was weakly significant. The commercial banks deposit rate proved to be the most sticky and uncompetitive in the financial market.

Based on these findings, the study recommends effective communication of the IT policy by the Bank of Ghana. The periodic monetary committee decisions on the prime rate should be effectively communicated to the general public through press releases and publications in the dailies, as well as other forms of the media. Economic agents will factor these policies in their decisions if they are fully aware and understand the policies better. Simultaneously, the Bank of Ghana should be committed to steering the economy along the inflation path that it sets for the economy. This will make the policy more credible and instil the confidence of the public in anchoring expectations. To ensure competition among commercial banks in the country, regular publishing of lending and deposit rates is needed to allow the public make informed decision on borrowing and saving. This should be done regularly as the prime rate is reviewed to make customers switch or bargain for interest rates. To further address the asymmetry between lenders and borrowers, the Credit Reference Bureau system should be strengthened to collect accurate data on borrower's characteristics to reduce default rate in the economy. It is important that commercial banks also consider factors such as default rate, profitability, operating expenses and several others in addition to the prime rate in determining their lending and deposit rates. The present paper could not consider all these variables. Notwithstanding, this does not affect the main results reported in this paper given that all the estimated models are cointegrated. 


\section{References}

Abradu-Otoo, P., Amoah, B., \& Bawumia, M. (2003). An investigation of the transmission mechanisms of monetary policy in Ghana: A structural vector error correction analysis. Bank of Ghana Working Paper, WP/BOG-2003/02.

Acheampong, K. (2005). Bank interest rate channel of monetary policy transmission in Ghana. Working Paper, 10. Bank of Ghana.

Amidu, M. (2006). The link between monetary policy and banks' lending behaviour: The Ghanaian case. Banks and Banking System, 1(4), 38-48.

Akosah N. K. (2015). Is the monetary policy rate effective? Recent evidence from Ghana. Working Paper No. NIHEIDWP14-2015, Bank of Ghana.

Aryeetey, E., \& Senbet, L.W. (2004). Essential financial market reforms in Africa. Technical Publication No. 63, Institute of Statistical, Social and Economic Research, University of Ghana, Legon.

Bawumia, M., \& Abradu-Otoo. P, (2003). Monetary growth, exchange rates and inflation in Ghana: An Error Correction Analysis. Working paper No. W/P BOG 2003/05, Bank of Ghana.

Bank of Ghana (2016a). Licensed banks, representative offices and their registered offices in Ghana. Bank of Ghana, September, 2016.

Bank of Ghana (2016b). List of NBFIs/Credit reference Bureaux as at June 2016. Bank of Ghana, June, 2016.

Bank of Ghana (2016c). List of 140 licensed rural and community banks by region. Bank of Ghana, April, 2016.

Bank of Ghana, (2012). Monetary policy framework. Bank of Ghana, http://www.bog.gov.gh

Biekpe, N. (2011). The competitiveness of commercial banks in Ghana. African Development Review, 23(1) 75-78.

Carlton, D. W. (1986). The rigidity of prices, American Economic Review, 76, 637-58.

CEPA (2012). Ghana Economic Review and Outlook. Centre for Policy Analysis (CEPA), Accra Ghana.

Charoenseang, J., \& Manakit, P. (2007). Thai monetary policy transmission in an inflation targeting era. Journal of Asian Economics, 18(1), 144-157.

Chong, B. S., Liu, M., \& Shrestha, K. (2006). Monetary transmission via the administered interest rates channel. Journal of Banking and Finance, 30(5), 1467-1484. 
Cook, T., and Hann, T. (1988). The effect of changes in the federal funds rate target on market interest rates in the 1970s'. Federal Reserve Bank of Richmond, Working Paper 88-4.

Cottarelli, C., \& Kourelis, A. (1994). Financial structure, bank lending rates and the transmission of monetary policy. IMF Working Papers, 41(4), 587-623.

De Bondt, G.J. (2005). Interest rate pass-through: empirical results for the Euro Area. Germany Economic Review, 6 (1), 37-78.

Dickey, D.A., \& Fuller, W.A. (1979). Distribution of the estimators for autoregressive time series with a unit root. Journal of The American Statistical Association, 74(366a), 427-431.

Dickey, D.A., \& Fuller, W.A. (1981). Likelihood ratio statistics for autoregressive time series with a unit root. Econometrica: Journal of The Econometric Society, 1057-1072.

Dutta, S., Bergen, M., Levy, D., \& Venable, R. (1999). Menu costs, posted prices, and multiproduct retailers. Journal of Money, Credit, and Banking, 31, 683-703.

Froyen T. R., \& Berument, H., (2009). Long-term interest rates under inflation targeting: The New Zealand experience, http://www.unc.edu/depts/econ/papers/NewZealand.October.09.pdf

Fukac, M., \& Baldini, A. (2014). Inflation and monetary policy transmission mechanism in Ghana, 2007-2014. IMF Working Paper.

Ghartey, E.E. (2005). Monetary policy on Ghana's term structure of interest rates: Effects and implications. The Institute of Economic Affairs, Accra, Ghana.

Guy, D., Paul, M., Miguel, S., \& Sunil, S. (1998). Inflation targeting as a framework for monetary policy. IMF Economic Issues, 15.

Hannan, T., \& Berger, A. (1991). The rigidity of prices: Evidence from banking industry. American Economic Review, 81(4), 938-945.

Hansen, B. E. (1992). Testing for parameter instability in linear models. Journal of Policy Modeling, 14(4), 517-533.

Heffernan, S.A. (1997). Modelling British interest rate adjustment: An error correction approach. Economica, 64(254), 211-231.

Hemachandra, W.M. (2011). Interest rate as a policy instrument-recent experience of Sri Lanka. Staff Studies, 39(1), 15-36

Hofmann, B., \& Mizen, P. (2004). Interest rate pass-through and monetary transmission: Evidence from individual financial institutions retail rate. Economica, 71(281), 99-123. 

journey into the Caucasian black box. Document de Travail, Working Paper.

Johansen, S. (1991). Estimation and hypothesis testing of co-integration vectors in Gaussian Vector Autoregressive Models. Econometrica: Journal of the Econometric Society, 59, 15511580 .

Johansen, S., Mosconi, R. \& Nielsen, B. (2000). Cointegration analysis in the presence of structural breaks in the deterministic trend. The Econometrics Journal, 3(2) 216-249.

Kleimeier, S., \& Sander, H. (2006). Expected versus unexpected monetary policy impulses and interest rate pass-through in Euro-zone retail banking markets. Journal of Banking and Finance, 30(7) 1839-1870.

Kovanen, A. (2011). Monetary policy transmission in Ghana: Does the interest rate channel work? IMF Working Paper No. 11/275.

Kwapil, C., \& Scharler, J. (2010). Interest rate pass-through, monetary policy rules and macroeconomic stability. Journal of International Money and Finance, 29(2), 236-251.

Kyereboah-Coleman, A. (2012). Inflation targeting and inflation management in Ghana. Journal of Financial Economic Policy, 4(1), 25-40.

Lim, G. C. (2001). Banking interest rate adjustment: Are they asymmetric? The Economic Record, 77(237), 135-147.

Lowe, P., \& Rohling, T. (1992). Loan rate stickiness: Theory and evidence. Economic Research Department. Reserve Bank of Australia. Discussion Paper 9206.

Madsen, J., \& Yang, Y. (1998). Asymmetric price adjustment in menu cost models. Journal of Economics, 68(3), 295-309.

Mahasi, J., \& Pokhriyal, G. P. (2013). Two stage interest rate pass through in Kenya. Journal of Emerging Trends in Economics and Management Science, 4(1), 54-56.

Malile, I. (2013). Asymmetry of interest rate pass-through in Albania. Academic Journal of Interdisciplinary Studies, 2(9), 539.

Maureen, B. (2008). IMF helps Ghana learn from others on inflation targets. IMF Survey Magazine, http://www.imf.org/external/pubs/ft/survey/so/2008/CAR021408A.htm

Misati, R. N., Nyamongo, E. M., \& Kamau, A. W. (2011). Interest rate pass-through in Kenya. International Journal of Development Issues, 10(2), 170-182.

Mishkin, F. S., \& Schmidt-Hebbel, F. (2007). Does inflation targeting make a difference? NBER Working Paper No. 12876. 
Owusu-Antwi, G., \& Antwi, J. (2013). Do financial sector reforms improve competition of banks? An application of Panzar and Rosse Model: The case of Ghanaian banks. International Journal of Financial Research, 4(3), 43.

Phillip, P.C.B. (1995). Fully modified least squares and vector autoregression. Econometrica: Journal of the Econometric Society, 63(5), 1023-1078.

Phillips, P.C.B., \& Perron, P. (1988). Testing for a unit root in time series regression. Biometrika, 75(2), 335-346.

PWC, (2014). Ghana banking survey: The future of banking in Ghana. What's next? http://www.pwc.com/en_GH/gh/assets/pdf/gh-banking-survey-2014.pdf

Quartey, P., \& Afful-Mensah, G. (2014). Financial and monetary policies in Ghana: A review of recent trends. Review of Development Finance, 4(2), 115-125.

Roley, V.V. \& Sellon, G H. (1995). Monetary policy action and long term interest rates. Economic Review-Federal Reserve Bank of Kansas City, 80(4), 73.

Roelands, S. (2012). Asymmetric interest rate-pass through from monetary policy: the role of bank regulation. University of Notre Dame.

Scholnick, B. (1996). Asymmetric adjustment of commercial banks interest rates: Evidence from Malaysia and Singapore. Journal of International Money and Finance, 15(3), 485-496.

Stals, C. (1999, March). Inflation targeting as an anchor for monetary policy in South Africa. In Address at a Breakfast Meeting of the Johannesburg Branch of the Institute of Bankers in South Africa. Johannesburg, 17.

Sznajderska, A. (2012). On the empirical evidence of asymmetry effects in the interest rate passthrough in Poland. National Bank of Poland Working Paper, No. 114.

Taylor, J.B. (1993). Discretion versus policy rules in practice. In Carnegie-Rochester conference series on public policy, 39, 195-214.

Ziorklui, S. Q. (2001). The impact of financial sector reforms on bank efficiency and financial deepening for savings mobilization in Ghana. African Economic Policy, Discussion Paper 81.

Zivot, E., \& Andrews, D. W. K. (2002). Further evidence on the great crash, the oil-price shock, and the unit-root hypothesis. Journal of Business \& Economic Statistics, 20(1), 25-44. 


\section{FIGURE}

Figure 1: Trends in the 91 and the 182 Treasury bill rates, the prime rate, the deposit interest rate, and the lending interest rate

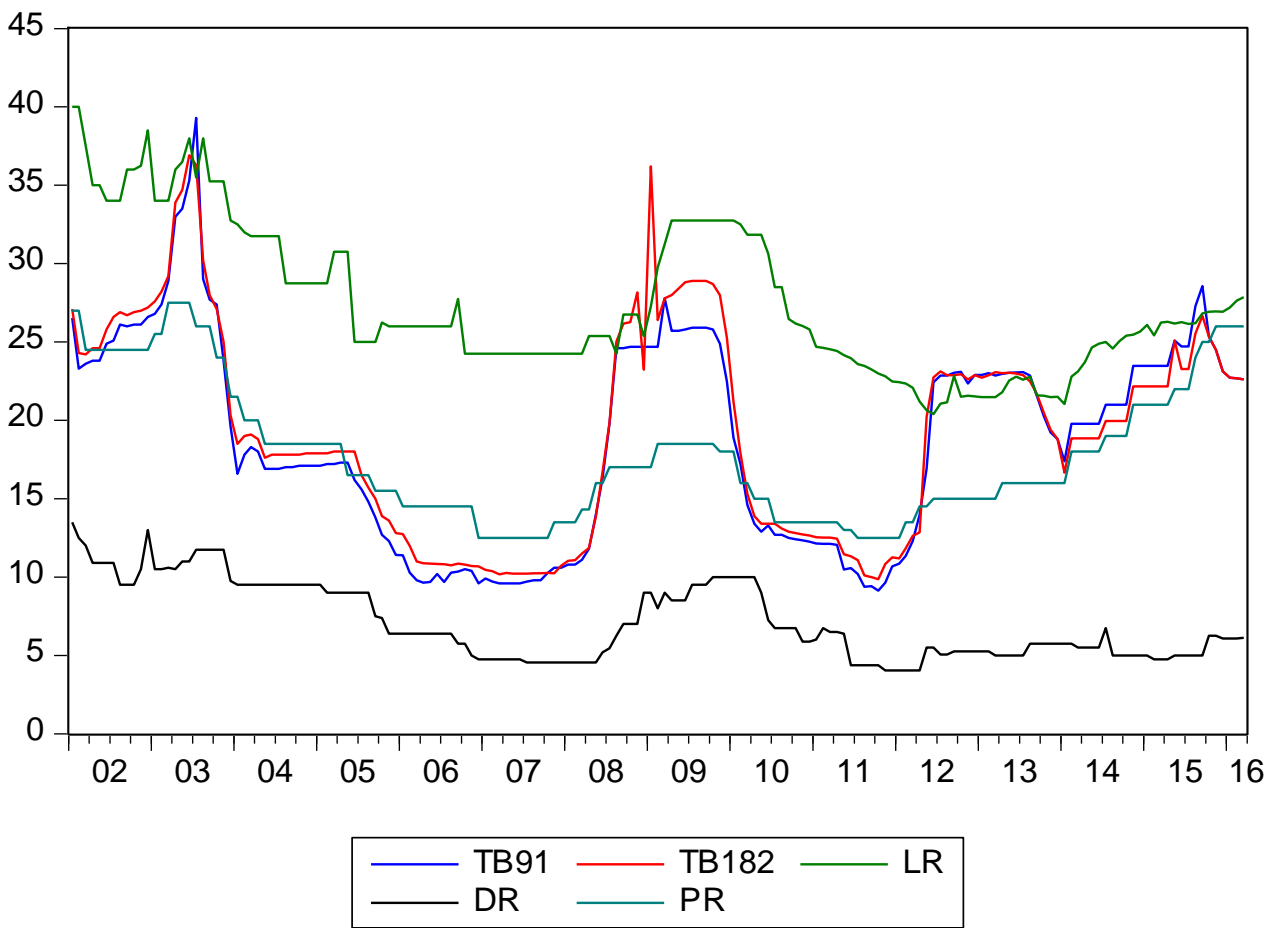

Note: Prime rate (PR), 91 Treasury bill rate (TB91), 182 Treasury bill rate (TB182), deposit interest rate (DR), lending interest rate (LR) 


\section{TABLES}

Table 1 Long run transmission of the prime rate to the respective interest rates

\begin{tabular}{|c|c|c|c|c|c|c|}
\hline \multicolumn{4}{|c|}{ FMOLS } & \multicolumn{3}{|c|}{ DOLS } \\
\hline $\begin{array}{l}\text { Dependent } \\
\text { Variables }\end{array}$ & $\left(\alpha_{1}\right)$ & $\begin{array}{l}\text { Standard } \\
\text { Error }\end{array}$ & $\begin{array}{l}\text { Hansen } \\
\text { (Lc) }\end{array}$ & $\left(\alpha_{1}\right)$ & $\begin{array}{l}\text { Standard } \\
\text { Error }\end{array}$ & $\begin{array}{l}\text { Hansen } \\
\text { (Lc) }\end{array}$ \\
\hline TBILL91 & $1.1541^{* * *}$ & 0.3970 & 0.2606 & $1.2002 * * *$ & 0.1531 & 0.0048 \\
\hline DR & $0.3201 * * *$ & 0.0735 & 0.3417 & $0.3197 * * *$ & 0.0420 & 0.0051 \\
\hline LR & $0.6531 * * *$ & 0.1729 & 0.1505 & $0.6579 * * *$ & 0.0840 & 0.0026 \\
\hline
\end{tabular}

Table 2 Short-run error-correction results

$\begin{array}{llll}\text { Variables } & \beta_{1} & \beta_{3} & \text { MAL }\end{array}$

\begin{tabular}{llll}
\hline$\Delta$ TBILL91 & $0.7700(0.00)$ & $-0.0800(0.0033)$ & 2.875 \\
\hline$\Delta$ DR & $0.0390(0.5852)$ & $-0.0740(0.0044)$ & 12.99 \\
\hline$\Delta$ LR & $0.2367(0.0762)$ & $-0.0582(0.0373)$ & 13.115
\end{tabular}

Note: $\beta_{1}$ is the short run transmission parameter of the prime rate and $\beta_{3}$ is the co-efficient of the error correction term. The values in parenthesis are the probabilities. $\Delta \mathrm{PR}$ is the independent variable

Table 3 Asymmetric short run adjustment results

\begin{tabular}{llccccc} 
Variables & $\pi_{1}$ & $\pi_{2}$ & $\pi_{3}$ & $\mathrm{MAL}^{+}$ & $\mathrm{MAL}^{-}$ & Wald Test \\
\hline$\Delta$ TBILL91 & $0.6275(0.00)$ & $0.0821(0.02)$ & $0.0690(0.15)$ & 4.54 & 5.40 & $7.6706(0.00)$ \\
\hline$\Delta$ DR & $0.1099(0.13)$ & $0.0323(0.38)$ & $0.0194(0.57)$ & 27.56 & 45.88 & $0.8295(0.48)$ \\
& & & & & & \\
\hline$\Delta$ LR & $0.3739(0.01)$ & $0.0308(0.42)$ & $0.0199(0.58)$ & 20.33 & 31.46 & $3.8683(0.02)$
\end{tabular}

Note: $\mathrm{MAL}^{+}=\left(1-\pi_{1}\right) / \pi_{2}$ is the mean adjustment lag when the degree of transmission is above equilibrium whiles $\mathrm{MAL}^{-}=\left(1-\pi_{1}\right) / \pi_{3}$ represents otherwise. The values in parenthesis are the probabilities. 


\section{APPENDIX}

\section{PRE-TEST TABLES}

Table A.1.1 ADF Unit Root Test Results

\begin{tabular}{ccccc}
\hline Variables & \multicolumn{2}{c}{ Levels } & \multicolumn{2}{c}{ First Difference } \\
\cline { 2 - 5 } TBILL91 & No Trend & Trend & No Trend & Trend \\
\cline { 2 - 5 } TBILL182 & -2.700414 & -2.695253 & $-10.15046^{* * *}$ & $-10.13675^{* * *}$ \\
DR & -2.272432 & -2.242162 & $-7.207494^{* * *}$ & $-7.201105^{* * *}$ \\
LR & -2.712473 & -2.528994 & $-13.50832^{* * *}$ & $-13.56125^{* * *}$ \\
PR & -2.732258 & -2.172058 & $-14.08135^{* * *}$ & $-14.29297^{* * *}$ \\
\hline
\end{tabular}

Source: Authors.

Note: *** indicates rejection of the null hypothesis of unit root at the 1 per cent level

Table A.1.2 PP Unit Root Test Results

\begin{tabular}{ccccc}
\hline \multirow{2}{*}{ Variables } & \multicolumn{2}{c}{ Levels } & \multicolumn{2}{c}{ First Difference } \\
\cline { 2 - 5 } TBILL91 & No Trend & Trend & No Trend & Trend \\
\cline { 2 - 5 } TBILL182 & -2.279772 & -2.259256 & $-14.48213^{* * *}$ & $-10.48790^{* * *}$ \\
DR & -2.7124737 & -2.341777 & $-14.48213^{* * *}$ & $-14.46807 * * *$ \\
LR & -2.731272 & -2.515755 & $-13.52190^{* * *}$ & $-13.57372 * * *$ \\
PR & -1.578466 & -2.164477 & $-14.04332 * * *$ & $-14.25354 * * *$ \\
\end{tabular}

Source: Authors.

Note: *** indicates rejection of the null hypothesis of unit root at the 1 per cent level.

Table A.1.3 Zandrews Unit Root Test Results

\begin{tabular}{lccc}
\hline Variables & Intercept & Trend & Intercept + Trend \\
\hline TBILL91 & -3.354 & -3.940 & -3.926 \\
TBILL182 & -2.807 & -3.158 & -3.292 \\
DR & -3.408 & -2.696 & -3.682 \\
LR & -2.705 & -2.619 & -2.856 \\
PR & -1.641 & -1.956 & -2.001 \\
\hline
\end{tabular}

Source: Authors.

Note: The 5 per cent critical values for the intercept, trend and intercept + trend models are -4.80 , -4.42 and -5.08 respectively. 
Table A.2.1 Johansen cointegration test for TBILL91

\begin{tabular}{|c|c|c|c|c|c|c|c|}
\hline \multicolumn{2}{|c|}{ Trace Test without Structural Break } & \multicolumn{4}{c|}{ Trace Test with Structural Break } \\
\hline $\begin{array}{c}\text { Hypothesized } \\
\text { No. of CE(s) }\end{array}$ & $\begin{array}{c}\text { Trace } \\
\text { Statistic }\end{array}$ & Prob. & $95 \%$ & $\begin{array}{c}\text { Hypothesized } \\
\text { No. of CE(s) }\end{array}$ & $\begin{array}{c}\text { Trace } \\
\text { Statistic }\end{array}$ & Prob. & $95 \%$ \\
\hline None* & 15.28941 & 0.0537 & 15.49471 & None* & 43.00 & 0.0096 & 36.79 \\
\hline At most 1 & 1.075528 & 0.2997 & 3.841466 & At most 1 & 6.43 & 0.8552 & 18.51 \\
\hline
\end{tabular}

Trace statistic indicates cointegration at the 0.05 level

* denotes rejection of the hypothesis at the 0.05 level

*** MacKinnon-Haug Michelis (1999) p-values

Table A.2.2 Johansen cointegration test for TBILL182

\begin{tabular}{|c|c|c|c|c|c|c|c|}
\hline \multicolumn{2}{|c|}{ Trace Test without Structural Break } & \multicolumn{3}{c|}{ Trace Test with Structural Break } \\
\hline $\begin{array}{c}\text { Hypothesized } \\
\text { No. of CE(s) }\end{array}$ & $\begin{array}{c}\text { Trace } \\
\text { Statistic }\end{array}$ & Prob. & $95 \%$ & $\begin{array}{c}\text { Hypothesized } \\
\text { No. of CE(s) }\end{array}$ & $\begin{array}{c}\text { Trace } \\
\text { Statistic }\end{array}$ & Prob. & $95 \%$ \\
\hline None & 12.47528 & 0.1355 & 15.49471 & None & 34.11 & 0.0934 & 36.79 \\
\hline At most 1 & 0.689058 & 0.4065 & 3.841466 & At most 1 & 5.30 & 0.9277 & 18.51 \\
\hline
\end{tabular}

Trace statistic indicates no cointegration at the 0.05 level

* denotes rejection of the hypothesis at the 0.05 level

*** MacKinnon-Haug Michelis (1999) p-values

Table A.2.3 Johansen cointegration test for DR

\begin{tabular}{|c|c|c|c|c|c|c|c|}
\hline \multicolumn{2}{|c|}{ Trace Test without Structural Break } & \multicolumn{4}{c|}{ Trace Test with Structural Break } \\
\hline $\begin{array}{c}\text { Hypothesized } \\
\text { No. of CE(s) }\end{array}$ & $\begin{array}{c}\text { Trace } \\
\text { Statistic }\end{array}$ & Prob. & $95 \%$ & $\begin{array}{c}\text { Hypothesized } \\
\text { No. of CE(s) }\end{array}$ & $\begin{array}{c}\text { Trace } \\
\text { Statistic }\end{array}$ & Prob. & $95 \%$ \\
\hline None* & 31.28796 & 0.0001 & 15.49471 & None* & 37.91 & 0.0352 & 36.50 \\
\hline At most 1 & 1.233810 & 0.2667 & 3.841466 & At most 1 & 6.16 & 0.8611 & 18.34 \\
\hline
\end{tabular}

Trace statistic indicates cointegration at the 0.05 level

* denotes rejection of the hypothesis at the 0.05 level

*** MacKinnon-Haug Michelis (1999) p-values

Table A.2.4 Johansen cointegration test for LR

\begin{tabular}{|c|c|c|c|c|c|c|c|}
\hline \multicolumn{3}{|c|}{ Trace Test without Structural Break } & \multicolumn{4}{c|}{ Trace Test with Structural Break } \\
\hline $\begin{array}{c}\text { Hypothesized } \\
\text { No. of CE(s) }\end{array}$ & $\begin{array}{c}\text { Trace } \\
\text { Statistic }\end{array}$ & Prob. & $95 \%$ & $\begin{array}{c}\text { Hypothesized } \\
\text { No. of CE(s) }\end{array}$ & $\begin{array}{c}\text { Trace } \\
\text { Statistic }\end{array}$ & Prob. & $95 \%$ \\
\hline None* & 27.44036 & 0.0005 & 15.49471 & None* & 52.88 & 0.0005 & 37.01 \\
\hline At most 1 & 0.788252 & 0.3746 & 3.841466 & At most 1 & 15.74 & 0.1264 & 18.68 \\
\hline
\end{tabular}

Trace statistic indicates cointegration at the 0.05 level

* denotes rejection of the hypothesis at the 0.05 level

*** MacKinnon-Haug Michelis (1999) p-values 